\title{
Strategy Implementation: A CONCEPTUAL Review of Practical Applications
}

\author{
James $F$. Van Houten \\ Mutual Service Insurance \\ St. Paul, Minnesota \\ V.K. Unni \\ Indiana University of Pennsylvania \\ Indiana, Pennsylvania
}

\section{Introduction}

When systematic strategic planning was first introduced, the initial focus was on diversification of the firm. But as firms increasingly faced strategic challenges from technological turbulence, changing competition, saturation of growth, and socio-political pressures, it became evident that the problems posed by these challenges could not be resolved simply by adding new areas to the firm [1]. As a result, attention was turned to optimizing the firm's competitive strategies. Corporate executives have continuously sought ever since to achieve such competitive advantage. Most significant business decisions involve substantial commitments with attendant uncertainties. Prominent writings on business strategy for practitioners, such as Michael Porter ([14], [15]), identify certain strategic options for a firm seeking advantage over its competitors. Porter's strategy proposals have been well received in the field of strategic management where they have been analyzed empirically and theoretically.

\section{Porter's Model}

Any business strategy, to be capable of sustained success, must be grounded in competitive advantage. Competitive advantage is gained when a company moves into a position where it has an edge in coping with competitive forces. According to Porter the intensity of competition is based on the economic structure of an industry and the state of competition in an industry depends on five basic competitive forces: (I) the threat of new entrants, (2) the threat of substitute products or services, (3) the bargaining power of suppliers, (4) the bargaining power of buyers, and (5) the rivalry among existing firms. The goal of competitive analysis is to find a position in the industry where the company can best defend itself against these competitive forces or can influence them in its favor.

In coping with the five competitive forces, Porter has identified three generic strategic approaches: (1) overall cost leadership, (2) differentiation, and (3) focus. Cost leadership emphasizes producing a standardized product at very low per-unit costs for many buyers who are price-sensitive. The impetus for striving to be the industry's low-cost producer can stem from sizable economies of scale and strong learning curve effects. Differentiation refers to outputs which are considered unique industry-wide and are addressed to many buyers who are relatively price-insensitive. Success differentiation creates lines of de- 
fense for dealing with competitive forces. Focus strategy adverts to products which fulfill the needs of particular buyers who are fewer in number in an industry. In this paper an attempt is made to operationalize Porter's model by reviewing the relationship of situational factors to competitive strategy, and by identifying the actions taken to implement the various competitive strategies in the real world.

\section{Data and Methodology}

The data used for analysis were collected from articles in three business periodicals (Business Week, Forbes, and Fortune) published during March 1988-89 ([2-13], [16-28]). A convenient sample of twenty-five firms was selected from eighteen different industry categories, with no more than three firms from any one category. Industry categories were also balanced between "manufacturing" and "service-retailing" classification. Since competitive strategy deals with long range sustainable advantages [14], it was important to separate long-term strategic from short-term tactical actions. The fundamental basis of above-average performance in the long run is defined as sustainable competitive advantage. This sorting of the sample size was accomplished by relying on the author's comments, and by selecting only those firms identified in the literature as in "turn-around" or "problem solving" modes. These firms seemed most likely to be taking significant long-term actions as opposed to making tactical adjustments. Table 1 lists the firms and industries selected as sample for the study.

\section{Table 1}

\section{Firms and Industries Selected for Analysis}

\section{Manufacturing:}

Autos: General Motors, Peugeot Motor of America

Chemicals: Cabot

Drugs: Miles Labs/A.G. Pharamaceuticals

Food Processing: General Mills, Kellog

General Mfg: Hillenbrand

Shoes: Keds/Stride Rite

Special Machinery: Caterpillar

Tires: Bridgestone

Writing Instruments: Parker

\section{Services and Retailing:}

Airlines: British Airways

Discount and Fashion Retailing: Goldblatt's, Sears

Financial Services: Equimark, Jeffries, Solomon

Jewelry Retailing: Tiffany

Marine Transportation: Sea Container

Oil and Gas: Dresser, Mobil, Occidental

Publishing: Knight-Ridder 
Each of the twenty-five firms were analyzed, and then classified on the basis of their environmental factors and competitive strategy selection. The environmental factors considered were the five identified by Porter as those which drive industry competition, and therefore, determine the environment in which the competitive strategy will be implemented.

Since each of these factors is present to some degree for each firm in every industry, one challenge was to identify those which seemed to be the dominant strategic choice factors. When the journal author expressed an opinion, the opinion was accepted as correct and this may be considered as a limitation to the study. In most cases, however, it was necessary to evaluate each author's comments against Porter's rationale, and subjectively establish the environmental factors which seemed most critical. Using this method it was possible to identify a single environmental factor as dominant for nine firms, and two factors for fifteen firms.

All firms were classified on the basis of past competitive strategies using Porter's three categories (differentiation, cost, and focus) whenever possible. This was possible in every case for current competitive strategies. However, the past strategies for eight of the twenty-five firms resisted any classification, and were identified as "unclear". Four additional firms seemed to be moving from unsuccessful strategies best described as conglomerate diversification. The past strategies for these four firms were identified as "conglomerate". The fact that twelve of these twenty-five "turn-around" firms were moving from competitive strategies that could not be clearly classified in the Porter model to strategies that could, seems to lend support to Porter's argument that, "the firm failing to develop its strategy in at least one of the three basic directions, is in an extremely poor strategic situation" [14].

\section{Analysis of Environmental Factors and Strategic Selection}

Table 2, lists the firms and a classification based on environmental factors and strategy selection. The environmental forces, in terms of the five factors in the Porter Model, are noted in column two, along with a narrative about the specific internal and extemal situational choice factors which created the environmental forces. The third column indicates the past and current competitive strategy pursued by each firm. A narrative of the specific implementation actions taken by the firm to deal with the internal and external situational choice factors is also included in this column. 
Table 2

\section{Analysis and Classification of Firms Based on Environment Factors and Competitive Strategy Selection}

$\underset{\text { Firm }}{\text { Industry }}$

1. Bridgestone (Tires)

2. British Airways (Airlines)

3. Cabot (Chemicals)

4. Cal Fed (Savings and Loan)

Environmental Forces
Situational Choice
Factors

Buyers, Rivalry

(Internal: mfg. facilities inefficient, poor union and distributor relations. External: slow industry growth, competitors using new technology.)

New Entrants, Rivalry (Internal: low employee productivity and poor union relations, slow decision making. External: outdated route structure, new entrants in most profitable routes, service and price based competition.)

\section{New Entrants \\ (Internal: diversified into natural gas and alloys, core bus. mfg. is outdated. External: new technology in core bus., slow growth in core bus. demand, depressed natural gas prices.)}

\section{Substitutes, Suppliers (Internal: diversified into}

\section{Strategic Choice Implementation Actions}
From Industry Differentiated to Industry Cost leadership (Internal: decentralized decision making, changing culture to get wider input, cost $=$ reduced mgmt. levels. External: investing in new technology to upgrade $\mathrm{mfg}$.

From Unclear to Segment Focus (Internal: new CEO, reduced mgmt. levels, new Board, sold unprofitable assets, cut employees, changing culture to emphasize service. External: new advertising agency, revised routes, invested in Concorde, acquired British Caledovia AL, joint venture with UL.)

\section{No Change: Industry Cost Leadership (Internal: invest in new technology, centralizing some functions to reduce cost, open new plants in Pacific Rim to reduce transportation costs. External: expand demand for core product by joint ventures with tire COS, investment in $R$ \& $D$ to find new uses.)}

\section{From Unclear to Segment Focus Internal: reduce cost by closing unprofitable branches}


5. Caterpillar (Special Machinery)

6. Dresser Industries (Petroleum Services)
7. Equimark (Banking) additional bus.

where had low share and limited expertise. External: new competition for same need with new products, new competitors in core business, high interest return demanded by suppliers of funds.)

\section{New Entrants, Rivalry (Internal: outdated mfg. plants, poor union relations, high wage costs and restrictive work rules. External: slow down in world wide construction equip. demand, shift in market toward smaller construction firms, dollar value fluctuations vs. other currency, new mfg. technology, new competition competition with lower cost)}

\section{Rivalry}

(Internal: diversified broadly into unrelated businesses. External: oil exploration core business demand declined, low shares in new businesses.)

\section{Buyers, Rivalry}

(Internal: poor quality loans decreased earnings, inefficient

operations, many

unprofitable locations.

External: market demand becoming more segmented sold assets not related to core bus., opened branches in profitable markets. External: product-adjustable rate mortgages to recuce risk of rising interest rates.)

From Industry Difierentiated to Industry Cost Leadership (Internal: cut number employees, renegotiated wages and work rules, installed computer inventory control, invested to modernize all plants. External: introduced new products for small construction firms, expanded into U.S. farm machinery and international markets.)

From Conglomerate to Segment Focus (Internal: new CEO, sold all businesses not related to core industry, pared capacity of core business to align with decreased demand, purchased M.W. Kellogg, Inc. to strengthen core bus.

External: joint ventures to reduce drilling costs.)

\footnotetext{
From Industry Difierentiated to Segment Focus (Internal: new CEO, cut staff $23 \%$, closed unprofitable locations, upgraded collection staff quality, sold low performing assets. External: focus marketing effort on
} 
and less homogeneous, power of large borrowers to negotiate rates.)

8. General Mills (Food Processing)

9. General Motors (Automobiles and Trucks)

10. Goldblatt's

Dept. Stores (Discount and Fashion Retailing)
Rivalry, Substitutes (Internal: diversified into large number of related businesses.

External: new products introduced by competitors in core business, changing customer preferences, slow industry growth.)

New Entrants, Rivalry (Internal: production costs higher than competitors, complex structure slowed decision making, culture resisted change. External: slower industry growth, changing customer design and style preferences, new mfg. technology, fluctuating value dollar vs. other currencies.)

New Entrants, Suppliers (Internal: expanded into unfamiliar upscale markets, many locations unprofitable. External: new low cost general competitors, many new entrants into upscale markets.) smaller firms, acquiring other banks and thrifts with strengths in small business lending.)

From Conglomerate to Industry Differentiated (Internal: sold non-food businesses, expanded Olive Garden restaurants, retired 22\% stock. External: introduced 260 new products in last 5 years.)

\section{No Change Industry Differentiated}

(Internal: acquired hitechnology firms, changed culture to emphasize quality, sold Terex and Frigidaire divisions, upgrading $\mathrm{mfg}$. plant technology, closed inefficient plants. External: purchased Lotus to take advantage of styling and design skills, moved more $\mathrm{mfg}$. outside U.S.)

From Unclear to Segment Focus (Internal: new CEO, closed stores in upscale markets, added 2 new stores in traditional inner city markets, more aggressive negotiating for low cost merchandise. External: advertising shifted to hand delivered circulars in adjacent target neighborhoods.) 
11. Hillenbrand Industries (General Manufacturing)

12. Jefiries and Company (Investment Banking)

13. Keds Division Stride Rite Corp. (Shoes)
Rivalry

(External: extended life expectancy and excess hospital capacity resulted in non-growth core businesses.)
New Entrants, Rivalry

(Internal: firm prosecuted for insider trading, many top employees left. External: more financial services firms moving into investment banking, new methods of business financing introduced, traditional large customers market avoid firm because of scandal.)

$\begin{array}{ll}\text { New Entrants, Substitutes } & \text { From Industry Cost Leadership to } \\ \text { (Internal: previous } & \text { Segment Focus } \\ \text { parent-Uniroyal-treated } & \text { (Internal: Uniroyal sold } \\ \text { bus. as cash cow, } & \text { division to Stride Rite in } \\ \text { competing on basis of } & 1982 \text {. External: introduced } \\ \text { price only, no focused } & \text { new products and colors for } \\ \text { distribution, identity } & \text { women's and children's } \\ \text { and share declining. } & \text { "canvas shoe" segment, heavy } \\ \text { External: lifestyle } & \text { advertising support, } \\ \text { changes created } & \text { distribution strategy }\end{array}$

From Segment Focus to Industry Cost Leadership (Internal: used earnings from core bus. to purchase additional firms in related bus., invested in technology to reduce mfg. costs, cut core bus. expenses, created 59 warehouse distr. system to improve service.

External: introduced new products in core and related bus., increased core bus. advt. to hold share, purchased Medeco Locks and American Tourister to take advantage of new low cost $\mathrm{mfg}$. technology and expertise.)

From Segment Focus to Industry Differentiated (Internal: new CEO, rebuild culture, more decentralized decision making. External: advertise to rebuild firm image, more emphasis on small as well as large customers, and broader services to all size customers.) 
14. Kellogg (Food Processing)
15. Knight-Ridder (Publishing)
16. Miles Laboratory Division, AG Pharmaceuticals (Drugs) numerous new segments, segments, each targeted by new competitors, generic type product no growth.)

\section{Rivalry, Substitutes}

(Internal: mgmt. lost touch with markets, culture resistant to change, outdated. mfg. facilities. External: demographic and lifestyle changes reduced demand for sweet tasting children's cereal, new mfg. technology.)

\section{New Entrants, Rivalry} (Internal: diversified into TV stations, poor relations with unions, poor printing plant efficiency. External: changing population in key markets-Hispanics, suburbs-new printing technology, new competitors in Latin language papers and stations.)

\section{Rivalry}

(External: lifestyle change toward over eating and drinking reduced industry demand for stomach upset and hangover remedies including Alka-Seltzer key product, many new concentrate on dept. stores and fashion retailers.)

\author{
From Unclear to Industry Difierentiated \\ (Internal: increased R \& D \\ spending, invested in new \\ mfg. technology. External: \\ increased advertising of \\ brand, introduced new products \\ emphasizing nutritional value, \\ attacked niches controlled by \\ competitors with me-too \\ products, expanded into \\ foreign markets, launched \\ twice as many new products \\ as competitors.)
}

\section{From Unclear to Segment Focus \\ (Internal: new CEO, new publishers at $1 / 3$ of papers, sold unprofitable-unfocused TV stations, acquired specific market cable stations. External: seeking newspaper acquisitions, introduced Spanish language supplements, cut ad rates, introduced zone editions for larger papers.)}

\section{No Change: Industry Difierentiated} (Internal: reorganized 178 person sales force into separate divisions for doctors, food stores, and Rx. External: new advt. agency, increase advt. expenditures, product line extensions, joint advt. with H\&R Block.) 
17. Mobil Corp. (Oil and Gas)
18. Occidental Petroleum (Oil and Gas)
19. Parker Pen (Writing Instruments) products for same

purpose introduced.)

\section{Rivalry}

(Internal: expanded into unrelated industries, expanded service stations into new regional markets, many unprofitable, refinery technology outdated, unsuccessful at finding new oil reserves. External: gas use decline, new refinery technology.)

\section{From Conglomerate to} Industry Cost Leadership (Internal: sold non-oil and gas businesses, sold stations too distant from refineries for low cost distribution, shut down least efficient refineries, purchased high tech. refinery from Tenneco, renovated service stations, reduced corp. staff by $33 \%$, acquired Superior Oil to increase reserves, investing in new exploration. External: opening new type of service station with fast food facilities in selected regional markets, marketing higher profit margin refinery products more aggressively.)

\section{Rivalry}

(Internal: heavy debt incurred to expand into unrelated businesses, heavy demand for cash flow, autocratic leadership of 90 year old CEO and founder. External: gas use decline, new refinery technology.)

Rivalry

(Internal: diversified into temporary employment business with Manpower acquisition. External: slow growth of premium pen market, aggressive competition
From Conglomerate to Industry Differentiated (Internal new COO taking over more of leadership from $\mathrm{CEO}$, changing culture to encourage broader mgmt. participation in decision making, sold non-core industry assets to pay down debt, increase investment in oil exploration, forward integration into distribution, acquired chemical businesses.)

From Unclear to Segment Focus (Internal: LBO of pen division from parent in 1985, new CEO, cut production capacity. External: new advt. to emphasize premium pen markets, increased advt. expenditures $60 \%$, introduced 
20. Peugeot Motors of America, Division of Peugeot Corp. (Automobiles)

21. Salomon, Inc. (Financial Services)

22. Sea Container Corp. (Ferry and Marine Freight Transport) among top 3 firms for low price pen market, new technology in $\mathrm{mfg}$. low price pens.)

New Entrants, Rivalry (Internal: low parent understanding of U.S. market, poor dealer relations, limited dealer representation and service facilities in some locations. External: slower industry growth, changing customer design and style preferences, new mfg. technology, fluctuation in value of dollar vs. other currencies.)

New Entrants, Substitutes, From Segment Focus to
From Unclear to Segment Focus (Internal: new CEO, improved parts delivery, closer relations with dealers, and more participation by them in decisions. External: parent won "car of the year" award in Europe, introduced it with increased advt.in U.S., narrow target mkt. advertising-direct mail to customers near dealer locations, cash awards for test drives, seeking new dealer outlets in target markets.) Rivalry

(Internal: autocratic CEO, culture resisted change. External: rely heavily on largest customers, needs of larger customers becoming more diverse, new business financing methods and services being introduced by both old and new competitors.)

Industry Differentiated (Internal: reshuffled top mgmt., provided incentives and internal partnership to reduce turnover, recruited experienced mgrs to run new institutional investment and banking depts, cut employees $10 \%$ to reduce costs, purchased a S \& L. External: reposition firm as provider of broad services with larger customers, increase advt. of broader services to all, expand stock trading to Asia.)

\section{Substitutes \\ (Internal: expanded to mfg. and supply all types of containers, acquired numerous ferries-many}

From Industry Differentiated to Segment Focus (Internal: cut payroll, closed unprofitable ferries, sold HO bldg and excess container capacity, shifted 
23. Sears, Roebuck and Co.

(Discount and Fashion Retailing)

24. Tiffany and Co. (Jewelry)

25. Union Pacific (Railroad) unprofitable, excess

mfg. and transport

capacity. External:

shipping industry losing

share to other

transporters. Overall

no growth, helicopters

and airlines competing

with ferries.)

New Entrants, Suppliers

(Internal: culture

resistant to change,

many unprofitable

locations, productivity

per square foot and

employee is low.

External: homogeneous market splitting into price and specialty store segments, many new competitors for each, customers less willing to buy store brands.)

New Entrants, Rivalry
(Internal: purchased
by Avon in 1979 and
changed emphasis to mid-
price premium items from
unique-exclusive items,
name recognition is
primary asset-but losing
awareness. External:
gold price fluctuations,
style changes, dept.
stores and other
entrants into premium
jewelry, slow growth in
market.)

Substitutes

(Internal: 74 year old CEO unwilling to change, poor union relations, mfg to specialty containers.

External: acquired

Hoverspeed, acquired

additional European ferries with strong mkt positions, refurbished remaining ferries.)
From Industry Differentiated to Industry Cost Leadership (Internal: selling HQ bldg, closing unprofitable stores, reducing number models carried to control inv. costs, cut promotional expenses. External: redesign stores, discount all items, discontinue annual sales promotions, opening new specialty children's stores, testing superstore concept.)

\section{From Industry Differentiated to} Segment Focus

(Internal: leveraged buy out from Avon in 1984, sold existing merchandise and replaced with unique-high priced items. External: new advt agency and ads, increased advt budget, started prestige catalogue business, added luxury fragrances, purses and silk scarves to branded category, made stores avail for high prestige charity events.)

\section{From Unclear to} Industry Cost Leadership (Internal: new CEO, sold HQ in NY and moved to Bethlehem, 


\begin{tabular}{|c|c|}
\hline $\begin{array}{l}\text { high wage costs and } \\
\text { restrictive work rules. } \\
\text { External: deregulation } \\
\text { increased price } \\
\text { competition for } \\
\text { traditional R.R. } \\
\text { dominated commodity } \\
\text { transport, airline fares } \\
\text { declined, market } \\
\text { demanding more comfort } \\
\text { and more dependable } \\
\text { service, new } \\
\text { scheduling and } \\
\text { communications } \\
\text { technology.) }\end{array}$ & $\begin{array}{l}\text { PA, reduced layers of mgmt., } \\
\text { cut jobs, closed outdated } \\
\text { repair yards, tied Sr. mgmt. } \\
\text { compensation to performance, } \\
\text { created customer service } \\
\text { culture. External: est. a } \\
\text { new natl. account sales staff } \\
\text { for large customers, replaced } \\
\text { distr. system of freight } \\
\text { forwarding agents with } \\
\text { national service center using } \\
\text { computer technology.) }\end{array}$ \\
\hline
\end{tabular}

\section{Discussion and Conclusions}

The relationships between the specific environmental forces and selected competitive strategy are shown in Table 3.

\section{Table 3}

$\begin{array}{lcccc}\begin{array}{l}\text { Environment } \\ \text { Force }\end{array} & \begin{array}{c}\text { No. Firms } \\ \text { Afiected }\end{array} & \begin{array}{c}\text { Selected Competitive Strategy } \\ \text { Cost Leadership }\end{array} & \begin{array}{c}\text { Difierentiation } \\ \text { Segment_Focis }\end{array} \\ \text { Buyers } & 2 & 1 & 0 & 1 \\ \text { New Entrants } & 12 & 3 & 3 & 6 \\ \text { Rivalry } & 18 & 4 & 7 & 7 \\ \text { Substitutes } & 7 & 1 & 3 & 3 \\ \text { Suppliers } & 3 & 1 & 0 & 2\end{array}$

The data does not suggest any dominance of certain Environment Forces, in-and-of themselves that may lead to specific competitive strategy choice. This is not in conflict with the Porter model, which states, "the best strategy for a given firm is ultimately a unique construction" [14].

The common requirements to effectively implement each strategy, as described by Porter, and the number of firms in this study that possess each of these requirements are summarized in Table 4. 
Table 4

Portion of Firms in Study that Possess the Most Common Requirements for the Selected Strategy

\begin{tabular}{lllll} 
Strategy & \multicolumn{2}{l}{ Skills or Resources } & & \multicolumn{2}{c}{ Common Organization Requirements } \\
\cline { 5 - 6 } Cost Leadership & Access to Capital & (7) & Tight Cost Control & (7) \\
(Total: 7) & Engineering Skills & (4) & Detailed Reports & (0) \\
& Labor Supervision & (2) & Structured Organization & (5) \\
& Easy to Mfg. Prods & (4) & Special Mgmt. Incentives & (1)
\end{tabular}

At least one of above

7

At least two of above 7

7

Three or more of above 4

5

1

$\begin{array}{lllll}\text { Industry } & \text { Marketing Skill } & \text { (5) } & \text { Strong Internal Coord. } & \text { (5) } \\ \text { Differentiation } & \text { Engineering Skill } & \text { (3) } & \text { Subjective Perf. Measure } & \text { (2) } \\ \text { (Total: 7) } & \text { Creative } & \text { (4) } & \text { Amenities to Attract Strong R\&D (4) } \\ & \text { Skilled Employees } & \text { (4) } & \text { Reputation } & \text { (4) } \\ & \text { Unique Skill } & \text { (7) } & \text { Channel Cooper } & \text { (4) }\end{array}$

$\begin{array}{llc}\text { At least one of above } & 7 & 6 \\ \text { At least two of above } & 7 & 3 \\ \text { At least three of above } & 5 & 2 \\ \text { Four or more of above } & 5 & \text { NA }\end{array}$

Segment Focus

(Total: 11)

At least one of above

At least two of above

At least three of above

Four or more of above
Some Combination of the Above Cost or

Differentiation Strengths Aimed at a Particular Segment

It should be noted that the data in Table 4 are the minimum number of satisfied criteria, because not all of the criteria could be verified for each firm from the articles reviewed. For example, the common requirement for "Detailed Reports" for the "Cost Leadership Strategy" was mentioned in none of the articles, but seems likely to exist in at least some of the firms. Only five of the twenty-five firms reviewed seemed to have situational factors that were in opposition to the selected strategy.

Despite these five possible conflicts, the model seems to do a good job reflecting the real world in the overall. All firms have at least some of the strengths needed to implement their selected competitive strategies, and the majority of the firms have all but one or two. 
Table 5 summarizes the percentage of firms in each competitive strategy category taking each of the general actions identified in the literature review.

\section{Table 5}

\section{Portions of Firms Taking Each Management Action}

\section{Catequry}

Competitive Strategy

\section{Organization}

Decentralize Dec. Making

57

Change Culture

14

Replace CEO

Redesign Mgmt. Incentives

\section{Differentiation Cost Leadership Eocus}

\section{Cost/Expense}

Reduce Mgmt.

Sell Unprofitable Assets

Cut \# Employees

Close Unprofit Locations

Sell Non-Core Businesses

Renegotiate Wages/Rules

\section{Marketing}

Change Advt. Agency

Change Advt. Strategy

Increase Advt. \$

Change Distr. System

14

29

14

14

14

0

14

43

57

43

29

71

Add New Products

Cut No. Products

\section{R\&D/Product Dev.}

Invest in R\&D

Core Business Expansion

Acquisition

Joint Venture

Invest New Tech.

Add Facilities

New Geog. Mkts.

Unrelated Bus. Expansion Acquisition

Core and Unrelated Bus. 
Firms implementing a Product Differentiation strategy were most likely to take actions to acquire additional businesses and add new products. They were least likely to cut their product portfolios or make it a high priority to renegotiate wage rates or work rules. Firms implementing a Cost Leadership strategy were most likely to take actions to invest in new technology, reduce management levels, and sell unprofitable assets. They were least likely to acquire businesses unrelated to their core industry or to change advertising. Firms implementing a Segment Focus strategy were most likely to take actions to replace their CEO and acquire additional businesses related to their core industry. All the above action patterns are similar to the strategic choice options indicated in the Porter's Model, and seem to relate logically to the general direction implied by each strategy.

The conceptual nature of this study makes it impossible to quantitatively conclude that the Porter Model is supported by the actions taken by firms in the real world. The lack of conflict between the model and paper indicate that the model fits the actions taken by at least some firms in the real world. However, in some firm comparisons, the results did not support the validity of Porter's Model and suggest further study in these few specific areas.

\section{References}

1. Ansoff, I.H. and McDonnell, E.J. Implanting Strategic Management, New York: Prentice Hall (1990).

2. Dobrzynski, Judith. "Is John Gutfreund Dreaming an Impossible Dream?" Business Week (February, 1989), pp. 98-103.

3. Hannon, K. "Fast, Fast Relief for Sour Sales." Forbes (December, 1988), pp. 252-254.

4. Heins, J. "Back on Course." Forbes (October, 1988), pp. 66-68.

5. Heins, J. “Unhealthy Growth.” Forbes (February, 1989), p. 56.

6. Henkoff, R. "This Cat is Acting Like a Tiger." Fortune (December, 1988), pp. 70-76

7. Jereski, L. "Back in the Game." Forbes (October, 1988), pp. 148-150.

8. Kitchen, S. "Riding the Crest of the Raves." Forbes (October, 1988), pp. 140-142.

9. Labich, K. “The Big Comeback at British Airways." Fortune (December, 1988), pp. 70-76.

10. Lappen, A. "No Jokes Please." Forbes (November, 1988), pp. 117-120.

11. Mack, T. "Integrated-and Determined to Stay that Way." Forbes (December, 1988), pp. 78-85.

12. Mack, T. “Murphy's Law.” Forbes (March, 1988), pp. 174-176. 
13. Mavcom, J. Jr. “Penmanship with a Flourish.” Forbes (April, 1989), pp. 152-154.

14. Porter, M.E. Competitive Strategy; Techniques for Analyzing Industries and Competitors. The Free Press Division, New York: McMillan Publishing Co., Inc. (1980).

15. Porter, M.E. Competitive Advantage. The Free Press Division, New York: McMillan Publishing Co., Inc. (1985).

16. Ramirez, A.. “Hammer Hits 90! Oxy Grown Up Too.” Fortune (November, 1988), pp. 59-64.

17. Schillev, Z. “Can Bridgestone Make the Climb?” Business Week (February, 1989), pp. 78-79.

18. Schine, E., and Freidman, J. "Life After Boyd? And How." Business Week (March, 1989), pp. 143.

19. Schroeder, M. “Allan Fellheimer Wears Combat Boots." Business Week (March, 1989), pp. 119120.

20. Sellers, P. “How King Kellogg Beat the Blahs." Fortune (August, 1988), pp. 54-55.

21. Sherman, S. “The Smutty Story of Cabot Corp." Fortune (December, 1988), pp. 130-138.

22. Taylor, J. “Knight-Ridder Shifts into High Gear.” Forbes (August, 1988), pp. 62-64.

23. Trachtenberg, J. “Cocktails at Tiffany.” Forbes (February, 1989), pp. 128-130.

24. Weiner, S. "Calling Betty Crocker." Forbes (August, 1988), pp. 88-89.

25. Weiner, S. "Don't Write Sears Off." Forbes (November, 1988), pp. 196-200.

26. Weiner, S. "Poor Customers, Rich Profits." Forbes (March, 1989), pp. 145-146.

27. Willoughby, J. “The Rebuilding of Uncle Pete." Forbes (November, 1988), pp. 182-190.

28. Woods, W. “The U.S. Must do What G.M. has Done." Fortune (February, 1989), pp. 70-73. 